\title{
Product Type and Personality in Brand Relationships
}

\author{
Chapter · May 2015
}

DOI: $10.1057 / 9781137427120 \_5$

CITATION

1

3 authors:
READS

244

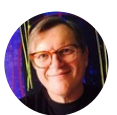

Ronald Voorn

University of Twente and University of Applie. .

4 PUBLICATIONS 25 CITATIONS

SEE PROFILE

Ad Pruyn

University of Twente

104 PUBLICATIONS 2,368 CITATIONS

SEE PROFILE

\section{Sabrina Hegner}

Fachhochschule Bielefeld

23 PUBLICATIONS 112 CITATIONS

SEE PROFILE

Some of the authors of this publication are also working on these related projects:

IRNet - International Research Network for study and development of new tools and methods for advanced pedagogical science in the field of ICT instruments, e-learning and intercultural competences View project PhD project on the experience of hospitality - Communication studies, University of Twente View project 
This file is to be used only for a purpose specified by Palgrave Macmillan, such as checking proofs, preparing an index, reviewing, endorsing or planning coursework/other institutional needs. You may store and print the file and share it with others helping you with the specified purpose, but under no circumstances may the file be distributed or otherwise made accessible to any other third parties without the express prior permission of Palgrave Macmillan.

Please contact rights@palgrave.com if you have any queries regarding use of the file.

\section{Part II}

\section{Personality and Social Groups, and Brand Relationships}




\title{
PROOF
}

\section{4 \\ Product Type and Personality in Brand Relationships}

\author{
Ronald Voorn, Sabrina Hegner, and Ad Pruyn
}

\section{Introduction}

Most manufacturers wish that all their customers would start a relationship with their brands. Not just any relationship but preferably one that is of an exclusive and loyal nature since this can be very beneficial (Sheth and Parvatiyar, 1995). This was also the central theme in the book Lovemarks (Roberts, 2004), which stipulated that great brands need more than just respect to earn undying loyalty from their consumers. In 2004, Roberts posited that respect for the brand is required, but that only when brand love is obtained can the hearts of followers be unlocked. Since then it seems as if brand love has become the Holy Grail for brand marketing research.

Brand love research is still in its infancy (Pang, Keh, and Peng, 2009) and finds its origin in the studies of consumer brand relationships that were first conceptualized in the nineties (Aaker and Fournier, 1995; Fournier, 1995, 1998). In most of these studies the interpersonal relationship metaphor was used to gain a better understanding of the different types of relationships between people and brands. It was posited that brands are contributing partners in relationships (Aaker, 1996; Aaker, 1997; Aaker and Fournier, 1995; Fournier, 1998). These relationships can be studied from different perspectives such as, for instance, the interpersonal norms on which they are based (Aggarwal, 2004), the intensity of the level of emotional attachment towards brands (Thomson et al., 2005), or even the kind of love relationship (Albert et al., 2008; Carroll and Ahuvia, 2006; Fetscherin and Conway Dato-on, 2012). With regard to the latter, Batra et al. (2012) developed a dimensional theory for brand love and found that obtaining it can be very beneficial. Its rewards are higher degrees of repurchase behavior, more positive word-of-mouth (WOM), and a stronger resistance to adverse brand news. 


\section{PROOF}

Assuming that brand love is an affective state (Batra et al., 2012), psychological research shows a strong link between that and personality traits. Building on the differential emotions theory of Izard (Izard, 1977; Izard and Malatesta, 1987), we propose that consumer personality not only plays an important part in human relationships but also in brand relationships (Lin, 2010; Matzler et al., 2006; Mulyanegara et al., 2009; Ozer and Benet-Martinez, 2006; Rauschnabel et al., 2013; Roberts et al., 2007). This is also the case with brand love. Using Costa and McCrae's (1992) Big Five personality traits model, Rauschnabel et al. (2013) show that people with a higher score on extraversion and neuroticism cultivate stronger brand love.

Besides the influence of personality traits on brand love, the authors of the present chapter will investigate the differential effect of product categories on brand love. Carroll and Ahuvia (2006) claim that it is relatively easier for hedonic and self-enhancing products to obtain brand love. Nevertheless, in relation to the field of consumer brand relationships, contradictory findings exist regarding the effects of product category on relationship quality. Christy et al. (1996), Veloutsou (2007), and Wilson (2011) point to a positive effect for the influence of high product category involvement on the brand relationship quality, whereas Valta (2013) finds no support at all. Current empirical studies on brand love, however, focus on a single product category from rather high-involvement categories like consumer electronics or apparel (Batra et al., 2012; Rauschnabel et al., 2013). This raises the question whether brand love can only be obtained in those product categories. An application of the Rossiter-Percy grid is thus carried out to measure the direct influence of product category on brand love. Furthermore, we explore whether product category offers an additional explanation for the varying results of personality traits on relationships. We propose that product category acts as a moderator between personality and brand love. Therefore, the research questions this study will seek to answer are the following:

RQ1: To what extent does personality influence brand love?

RQ2: To what extent does the product category influence brand love?

$R Q 3:$ To what extent does the product category moderate the relationship between personality and brand love?

This study seeks to expand the current knowledge by contributing additional insights into the influence of the product category on the 
relationship between personality and brand love. This will assist the further development of the theory of consumer-brand relationships as well as assist practitioners in developing better brand building programs. For the concept of brand love, the prototype of Batra et al. (2012) will be used in this study since it is an empirically constituted grounded prototype.

\section{Theoretical framework}

\subsection{Brand love}

Perspectives in marketing have changed from an economic exchange focus to a relationship perspective between consumers and brands (Fournier, 1995, 1998). According to Veloutsou (2007), the economic exchange element is still a valid layer in the consumer behavior process but "the addition of the relationship is due to the increased sophistication of the exchange process and in some occasions satisfies a secondary need for interaction" (p. 21).

Brand love is one of the more recent types of relationship that has been added to the spectrum of possible consumer-brand relationships (Pang et al., 2009). Building on the interpersonal relationship theory approach, Carroll and Ahuvia (2006) conducted a study to investigate long-term relationships between consumers and brands. These are described as brand love relations, which Carroll and Ahuvia (2006) defined as "the degree of passionate emotional attachment a satisfied consumer has for a particular trade name" (p. 81). As a main outcome they find that brand love exists and helps predict brand loyalty and positive WOM for self-expressive and hedonistic brands. They make a clear distinction, however, between brand liking and brand love. The latter is described as a more enduring and deeper continuum distinctly different from the concept of liking a brand. Consumers who love a brand have usually integrated the brand into their selves and have a long-term relationship with it. Although Carroll and Ahuvia (2006) also recognize that consumers can use the expression "I love a brand" loosely, they do not exclude the possibility entirely that consumers can sometimes experience their relationship with a brand "as fully analogous to the stronger forms of interpersonal love" (p. 81).

In their study, however, Albert et al. (2008) claim that brand love is a culturally determined phenomenon and is not covered completely by any single interpersonal love theory. They claim that the concept of love is culturally grounded and can never be the same as love for a 


\section{PROOF}

person, at least not for French consumers. Rather than the possibility to describe the connections with brands in terms of love or relationships, they find a set of characteristics and dimensions. French consumers use the words 'adoring' and 'liking,' but not the word love to describe their feelings toward brands. Likewise avoiding the analogy with interpersonal love, Fetscherin and Conway Dato-on (2012) posit that the love relations between consumers and brands are more similar to parasocial love, the sort of relationship that one can have with celebrities, which is by definition a one-directional relationship since brands cannot love people back. They define brand love as "a multidimensional construct consisting of a satisfied consumer's experience with a brand, which leads not only to brand loyalty (a predecessor of brand love) but to a deeply emotional relationship" (p. 151).

One major difference from other studies of brand love is Batra et al. (2012) are showing that brand love is mostly considered a less important relationship. It does not contain any of the acts of altruism normally associated with interpersonal love since a brand cannot love people back. Therefore they conclude that although theories on interpersonal love might seem a logical and tempting place to start, one needs to check carefully whether the analogy is correct and an appropriate basis for developing better insights into the concept of brand love. They raise the point that similarities between brand and interpersonal love should be studied empirically and go one step further by organizing a grounded prototype study that reveals seven factors that constitute brand love. These are respectively

1. self-brand integration (SBI), the degree to which the brand expresses a consumer's identities and deeply held beliefs about life as well as its salience;

2. passionate desire to use (PDU), the degree to which a consumer desires to spend time with the brand and invest other resources in it both in the future and the past;

3. positive emotional connection (PEC), the degree to which the brand fits naturally into a consumer's life;

4. anxiety separation distress (ASD), the degree of fear experienced should the brand cease to exist;

5. long-term relationship (LTR), the intention of continued future use and willingness for a long-term relationship;

6. positive attitude valence (AV); and

7. attitude strength (AS), robust and firm convictions. 
Additionally, brand love scores on this prototype demonstrate three consequences: repeat purchase intention, positive word-of-mouth intention, and increased resistance to adverse brand information. Below we will discuss the concept of personality traits and its relationship with affective states in general and brand love in particular.

\subsection{Personality}

Personality traits can be defined as "relatively enduring patterns of thoughts, feelings and behaviors that represent a readiness to respond in particular ways to specific environmental cues" (Fayard et al., 2012, p. 1). Personality is measured by using the personality theory as developed by McCrae and John (1992) and which describes personality as "the most important ways in which individuals differ in their enduring emotional, interpersonal, experiential, attitudinal, and motivational styles", (p. 175). In their Five-Factor Model (FFM), also called the Big Five model, McCrae and John (1992) describe the following personality dimensions:

1. openness (the degree to which one is open to new experiences)

2. conscientiousness (the level of planning needed in one's life)

3. extraversion (the need to seek company of others)

4. agreeableness (the degree of helpfulness towards others)

5. neuroticism (the individual's level of emotional stability)

These enduring factors and their combinations, which are different for every individual, determine to a great extent how people act in their social life toward others, including brands. Based on Izard's Differential Emotions Theory, it is assumed that that there is a strong and conceptually consistent relation between emotional experiences and traits of personality. (Izard, 1977; Izard and Malatesta, 1987). As such, there has been considerable research on the link between personality and affective states, with the link between extraversion and positive affect, and neuroticism and negative affect being well established (Rusting and Larsen, 1997). Conscientiousness is linked to both positive and negative affect (Watson et al., 1988; Fayard et al., 2012). Especially, agreeableness refers to emotional dispositions in relationships (e.g., Kubiak et al., 2007; Tobin et al., 2000). Individuals who score high on openness to experience seem to experience a wider range of feelings and emotions than people low on this trait (McCrae, 2007; Terracciano et al., 2003); hence, these individuals seem to be more open to loving experiences that transcend traditional interpersonal relationships. As brand love is 
defined as a positive affective state, this relationship should also hold true for the research object of brand love and its dimensions.

Additionally, research shows that in human relationships higher levels of openness, extraversion, agreeableness, and in particular lower levels of neuroticism are usually correlated with higher degrees of interpersonal relationship quality (Heller et al., 2004; Ozer and Benet-Martinez, 2006). Personality traits also help explain negative relationship outcomes. Ozer and Benet-Martinez (2006), as well as Roberts et al. (2007) report that neuroticism and low agreeableness are predictors for negative relationship outcomes.

In research on the influence of personality traits in relationship with brands, extraversion was regularly found to have an influence (Lin, 2010; Matzler et al., 2006; Mulyanegara et al., 2009; Rauschnabel et al., 2013). In that sense, Mulyanegara et al. (2009) demonstrate that more extroverted consumers rather engage in relationships with more sociable brands and that conscientious consumer's value trust in brands with which they interact. This was also confirmed for extraversion by Matzler et al. (2006) and further strengthened by Lin (2010), who presents another example of extraversion's positively predicting the relation with existing brands in a study involving toys and video games. In their study on the relation between brand love and personality traits, Rauschnabel et al. (2013) also find that a higher score on extroversion predicts a higher score on brand love. Therefore this study proposes H1: Extroversion is positively associated with brand love and its dimensions.

Following interpersonal relationship theory and the role of personality in this, Rauschnabel et al. (2013) predicted that neuroticism plays a different role in the brand love relationship compared to interpersonal relationships. The researchers theorized that people with higher scores on neuroticism have lower quality interpersonal relationships, which is in line with accepted theory (Heller et al., 2004), and would therefore use brands to compensate for the lack of love they might experience in their current human relationships. The results of their study showed indeed clear proof of this. In light of these findings, this study proposes H2: Neuroticism is positively associated with brand love and its dimensions.

On openness, the findings in extant consumer brand relationship research are more diverse. Matzler et al. (2006) report a positive relation with brand. The authors found that extroversion and openness are positively related to hedonic product value and that openness directly and extroversion indirectly influence brand affect. Therefore, we propose H3: Openness is positively associated with brand love and its dimensions. 
Lin (2010) reports a significant predictive relation between agreeableness and brand relationship. A higher score on agreeableness is linked to trust, compliance, and altruism (Costa and McCrae, 1992), which is usually a predictor for a higher quality of relationship (Heller et al., 2004; Ozer and Benet-Martinez, 2006). For this reason, this study proposes H4: Agreeableness is positively associated with brand love and its dimensions.

No significant literature was found indicating a relationship between conscientiousness and brand love. Moreover, in the specific study on the relation between personality and brand love by Rauschnabel et al. (2013), no relationship was found between this trait and brand love either. Hence this study proposes no hypotheses on the relationship between the conscientiousness trait and brand love.

\subsection{The role of product category type}

The role that the product category plays has regularly been the subject of study in the field of marketing research. One of the earlier studies on this subject was carried out by Vaughn (1980), who developed a model for the advertising agency Foote Cone and Belding (FCB model), which posited that products (and brands) could be divided into two separate dichotomies: thinking or feeling, and high and low involvement. It was proposed that people had different relations and needs toward products in each of the possible four combinations. Further evidence was found in a study by Claeys et al. (1995). Their study shows that products in the 'thinking' category needed predominantly informational advertising and 'feeling' products would benefit from self-enhancing, more image-related advertising.

Rossiter et al. (1991) extended the FCB model further to the RossiterPercy grid (RP grid) by combining the motivational product type to which a product belongs with the level of involvement (see Figure 4.1).

In the RP grid, products are divided into four quadrants. These are determined according to the level of involvement (high versus low) and the type of motivation involved (informational and transformational). The level of involvement with a product is determined by the degree to which the target group perceives a risk with the selection and purchase. These risks can be of a monetary, social, or psychological nature such as value-, personality-, or self-expressive functions (Percy and Rosenbaum-Elliott, 2012; Rossiter et al., 1991). If the perceived risk is higher, more elaboration will be triggered (Johnson and Eagly, 1989), whereby involvement acts as a moderator on brand evaluations (Petty et al., 1983; Petty and Cacioppo, 1986) and the quality of brand relationships (Wilson, 2011). 


\begin{tabular}{|c|c|c|c|}
\hline & \multicolumn{2}{|c|}{ Type of Motivation } \\
\hline & & Informational & Transformational \\
\hline \multirow{2}{*}{$\begin{array}{c}\text { Type of } \\
\text { Decision }\end{array}$} & $\begin{array}{c}\text { Low } \\
\text { Involvement }\end{array}$ & $\begin{array}{l}\text { Typical product categories } \\
\text { (Brands may differ) } \\
\text { - Aspirin } \\
\text { - Light beer } \\
\text { - Detergents } \\
\text { - Routine industrial products }\end{array}$ & $\begin{array}{l}\text { Typical product categories } \\
\text { (Brands may differ) } \\
\text { - Candy } \\
\text { - Regular beer } \\
\text { - Fiction novels }\end{array}$ \\
\hline & $\begin{array}{c}\text { High } \\
\text { Involvement }\end{array}$ & $\begin{array}{l}\text { Typical product categories } \\
\text { (Brands may differ) } \\
\text { - Microwave oven } \\
\text { - Insurance } \\
\text { - Home renovation } \\
\text { - New industrial products }\end{array}$ & $\begin{array}{l}\text { Typical product categories } \\
\text { (Brands may differ) } \\
\text { - Vacation } \\
\text { - Fashion/Clothing } \\
\text { - Cars } \\
\text { - Corporate image }\end{array}$ \\
\hline
\end{tabular}

Figure 4.1 The Rossiter-Percy grid, 1991

Note: We divided products according to the level of involvement and type of motivation.

The types of motivation that are distinguished in the RP grid are based on either the problem-solving qualities of a product (informational) or their gratification potential (transformational). In the first case, products are predominantly chosen for their ability to solve problems for consumers who require mainly factual information (Rossiter et al., 1991). The transformational products are chosen for their ability to bring consumers into a desired "sensory, mental, or social state" (p. 16). Utilitarian or informational products, due to their very nature, contain fewer attributes of a social, self-, or value-expressive kind than transformational products. They exist to solve problems. Hedonic and self-expressive products and brands, on the other hand, transform their consumers into a desired state, whether that is of an intellectual, social, or self-gratifying nature. Rossiter et al. (1991) notice a lower brand appreciation score for utilitarian products and higher scores for value- or selfexpressive products. This is confirmed in a study by Carroll and Ahuvia (2006), who add to this by stating that it is relatively easier for hedonic and self-enhancing products to obtain brand love.

Although some studies address the influence of product categories on the relationships between people and brands, little is still really known 
about this, particularly where it involves brand love. In the field of consumer brand relationships, there are even conflicting opinions on the effects of product category on relationship quality. Christy et al. (1996), Veloutsou (2007), and also Wilson (2011) point to a positive effect for the influence of high product category involvement on the brand relationship quality, while others find no support at all (Valta, 2013). Even though it seems that the influence of involvement on the relationship quality is controversial, there are still sufficient indications, however, that the motivational type to which a product belongs has a direct effect (Carroll and Ahuvia, 2006; Rossiter et al., 1991; Veloutsou, 2007). It is therefore hypothesized that the product category influences brand love and its dimensions. Therefore, we propose H5: Product category influences brand love and its dimensions. In particular, high-involvement products and transformational products lead to higher brand love scores compared to low-involvement and informational products.

Additionally, the authors wonder whether there is a moderating influence of the product categories on the relationship between personality traits and brand love. As research shows no clear pattern of the relationship between personality and affective states toward brands, we assume that the product category plays a moderating role between personality and consumer relationships. For instance, research shows that extraversion is linked with hedonism affecting brand emotions (Matzler et al., 2006), thus indicating that the product category might present an explanatory predictor for the varying results of personality on consumer relationships. To the best of our knowledge, no subsequent research to date has investigated this moderating relationship. Therefore, this study represents the first exploratory research to examine this effect.

Analyzing the interaction of the RP grid and personality traits on the separate brand love elements, we expect the transformational category to have a much more profound interaction than the other three. This is primarily due to the high symbolic and self-enhancing value that products in this category tend to have for consumers (Carroll and Ahuvia, 2006; Rossiter et al. 1991; Vaughn, 1980). Therefore H6 reads as follows: Product category influences the relationship of personality traits on brand love and its dimensions.

The effect of the independent variable of personality (as defined by the big five), moderated by product category, on the brand love prototype and its elements is captured in our proposed model for this study and is presented in Figure 4.2. 


\section{PROOF}

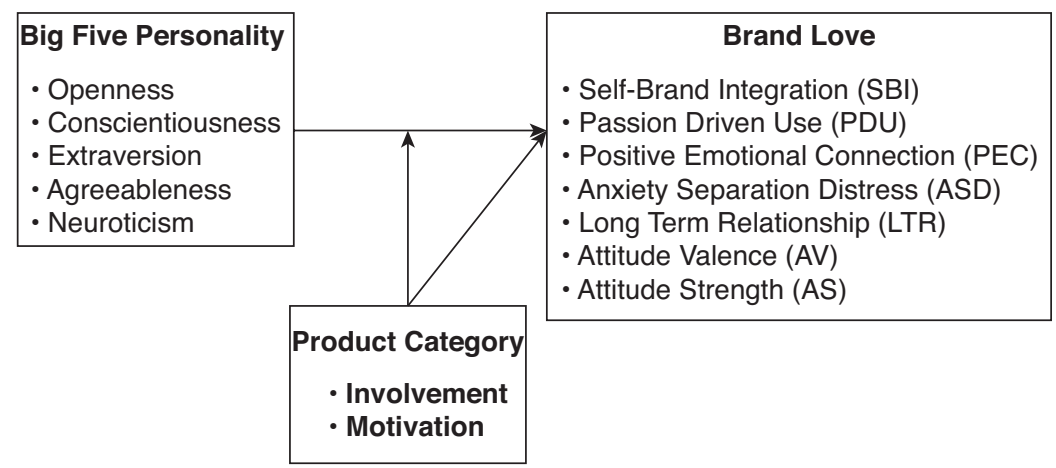

Figure 4.2 The influence of the Big Five on brand love moderated by product category

\section{Methodology}

\subsection{Pretest}

An online pretest was organized with a convenience sample of 30 students, who were familiar with the RP grid, to obtain two products per grid category. The students were requested to score 30 products on the criteria of involvement (low or high) and product type need (informational or transformational). The two most pronounced products per RP grid category were selected. These were the following products and their scores per RP grid category:

1. high-involvement and informational (HII): insurance (24) and laptop (23)

2. low-involvement and informational (LII): toilet paper (19) and detergent (16)

3. high-involvement and transformational (HIT): shoes (23) and clothing (21)

4. low-involvement and transformational (LIT): ice cream (22) and beer (14)

For each of these four product categories, one prominent brand was selected based on its market share in the Netherlands.

\subsection{Measures and participants}

The Big Five personality traits were measured with the ten-item scale of Hofmans et al. (2008) validated for the Dutch language and based on the Costa and McCrae (1992) NEO-FFI-scale. The reliability of the Big 
Five scales is assessed with the Spearman-Brown formula as it is appropriate for a two-item measure (Eisinga et al., 2012). Acceptable range is between .60 and .90 . The values range between .36 (openness) and .74 (extroversion), which is very low; nevertheless, as it is only a two-item scale with one reverse coded item, the values are acceptable. A study by Rammstedt and John (2007) shows that even with a reduction from 44 to 10 items to measure personality, the scale retains a substantial portion of the reliability and validity of the original instrument.

Brand love is measured with a shortened 27-item scale based on the work of Batra et al. (2012). Interitem reliability of the 27-item brand love scale is analyzed using Cronbach's alpha. The scale reliabilities are between .74 and .89 for the single brand elements, and therefore exceed the standard value of 7 (Nunnally, 1978). Additionally, composite reliability and average variance extracted show values greater than .6 and .5 (Bagozzi et al., 1991). Discriminant validity is tested and established following the procedures of Fornell and Larcker (1981).

The respondents were assigned at random to a questionnaire with one brand for the assessment of the assumed relationship. The respondent had to be familiar with the brand in order to proceed with the questionnaire. Four hundred ten Dutch students completed the online questionnaire. The respondents' age was between 18 and 26 with an average age of 22.3 (SD = 2.26). Of the respondents, 120 (29.3\%) were male and 290 female (70.7\%).

\section{Results}

\subsection{The relation between personality and the brand love prototype}

A multiple regression analysis is conducted to predict the brand love mean score from openness $(\mathrm{O})$, conscientiousness $(\mathrm{C})$, extroversion $(\mathrm{E})$, agreeableness $(\mathrm{A})$, and neuroticism $(\mathrm{N})$. In general, personality predicts 1.6 percent $\left(\mathrm{R}^{2}=.016\right)$ of the brand love prototype. Of the big five, only openness added statistically significantly to the predicted brand love mean, $F(5,404)=.845, p<.05$, adj. $\mathrm{R}^{2}=.004$. Regression coefficients and significance level can be found in Table 4.1 .

Based on these findings, hypotheses $\mathrm{H} 1, \mathrm{H} 2$, and $\mathrm{H} 4$ have no support. Therefore, openness is the only big five personality trait to significantly predict the brand love prototype. H3 is therefore supported.

Additionally, we checked the influence of personality traits on the individual brand love dimensions. Again, only openness has a significant influence. Two effects are found from openness on anxiety separation distress $(\beta=.110, \mathrm{p}=.029)$ and positive emotional connection $(\beta=.118, \mathrm{p}=.019)$. 
Table 4.1 Summary of multiple regression analysis for predicting brand love by the big five

\begin{tabular}{lccccc}
\hline Big five & $\boldsymbol{B}$ & $\boldsymbol{S E} \boldsymbol{B}$ & $\boldsymbol{\beta}$ & $\boldsymbol{t}$ & Sig. $(\boldsymbol{p})$ \\
\hline Openness & .088 & .039 & .115 & 2.287 & $.023^{*}$ \\
Conscientiousness & -.018 & .033 & -.027 & -.551 & .582 \\
Extroversion & -.008 & .032 & -.013 & -.265 & .791 \\
Agreeableness & .006 & .047 & .007 & .132 & .895 \\
Neuroticism & .027 & .036 & .037 & .735 & .463 \\
\hline
\end{tabular}

Note: ${ }^{*} p<0.05,{ }^{* *} p<0.01,{ }^{* * *} p<0.001$.

\subsection{The relation between product category and the} brand love prototype

The influence of the two RP grid dimensions, involvement and motivation, on overall brand love and its dimensions were tested using independent t-tests. This study found that transformational products had statistically significantly higher brand love scores $(\mathrm{M}=1.97)$ compared to informational products $(\mathrm{M}=1.72)$, [ $\mathrm{t}(345)=-5.961, \mathrm{p}=.000]$, while high-involvement products $(\mathrm{M}=1.88)$ do not lead to higher brand love scores compared to low-involvement products $(\mathrm{M}=1.81),[\mathrm{t}(345)=$ 1.692, $\mathrm{p}=.092]$.

Regarding the single dimensions of brand love, the results can be found in Table 4.2. These show that transformational products reach higher brand love on the dimensions self-brand integration, passiondriven use, positive emotional connection, long-term relationship, attitude valence, and attitude strength compared to informational products. Additionally, high-involvement products lead to higher brand love scores on the dimensions self-brand integration, positive emotional connection, and anxiety separation distress compared to low-involvement products.

\subsection{Tests of the moderator effect of product category involvement and motivational group}

To obtain a better understanding of the influence of product category on the relationship between personality and brand love, the separate brand love elements, univariate and multivariate analyses of covariance were performed. No interaction effects were found on overall brand love, but the single brand love dimensions yielded several significant results. In Table 4.3 the results are reported for those interactions that have a significance level below $\mathrm{p}<.1$. Due to the exploratory nature of our study, the threshold of significance was set to $\mathrm{p}=.10$ (Burns et al., 1990). 


\section{PROOF}

Product Type and Personality in Brand Relationships

Table 4.2 Results from the independent t-test

\begin{tabular}{|c|c|c|c|c|}
\hline Product category & $\begin{array}{l}\text { Brand Love } \\
\text { Dimension }\end{array}$ & Mean & T-value & Sig. $(p)$ \\
\hline Trans & \multirow[t]{4}{*}{ SBI } & 1.64 & \multirow[t]{2}{*}{-2.09} & \multirow[t]{2}{*}{$.037^{* *}$} \\
\hline Info & & 1.45 & & \\
\hline HI & & 1.70 & \multirow[t]{2}{*}{3.59} & \multirow[t]{2}{*}{$.000^{\star *}$} \\
\hline LI & & 1.38 & & \\
\hline Trans & \multirow[t]{4}{*}{ PDU } & 2.00 & \multirow[t]{2}{*}{-4.83} & \multirow[t]{2}{*}{$.000^{\star \star \star}$} \\
\hline Info & & 1.53 & & \\
\hline $\mathrm{HI}$ & & 1.83 & \multirow[t]{2}{*}{1.26} & \multirow[t]{2}{*}{.209} \\
\hline LI & & 1.70 & & \\
\hline Trans & \multirow[t]{4}{*}{ PEC } & 2.13 & \multirow[t]{2}{*}{-4.84} & \multirow[t]{2}{*}{$.000^{* * *}$} \\
\hline Info & & 1.66 & & \\
\hline $\mathrm{HI}$ & & 2.11 & \multirow[t]{2}{*}{4.46} & \multirow[t]{2}{*}{$.000^{\star \star *}$} \\
\hline LI & & 1.67 & & \\
\hline Trans & \multirow[t]{4}{*}{ ASD } & 1.38 & \multirow[t]{2}{*}{.25} & \multirow[t]{2}{*}{.806} \\
\hline Info & & 1.40 & & \\
\hline $\mathrm{HI}$ & & 1.56 & \multirow[t]{2}{*}{3.97} & \multirow[t]{2}{*}{$.000^{\star * *}$} \\
\hline LI & & 1.20 & & \\
\hline Trans & \multirow[t]{4}{*}{ LTR } & 2.36 & \multirow[t]{2}{*}{-4.01} & \multirow[t]{2}{*}{$.000^{\star * *}$} \\
\hline Info & & 1.71 & & \\
\hline HI & & 2.17 & \multirow[t]{2}{*}{1.61} & \multirow[t]{2}{*}{.108} \\
\hline LI & & 1.91 & & \\
\hline Trans & \multirow[t]{4}{*}{ AV } & 5.65 & \multirow[t]{2}{*}{-4.97} & \multirow[t]{2}{*}{$.000^{\star \star \star}$} \\
\hline Info & & 4.85 & & \\
\hline HI & & 5.23 & \multirow[t]{2}{*}{-.42} & \multirow[t]{2}{*}{.673} \\
\hline LI & & 5.30 & & \\
\hline Trans & \multirow[t]{4}{*}{ AS } & 6.00 & \multirow[t]{2}{*}{-3.81} & $.000^{* * *}$ \\
\hline Info & & 5.25 & & \\
\hline HI & & 5.64 & .05 & .964 \\
\hline LI & & 5.63 & & \\
\hline
\end{tabular}

Note: $H I=$ high involvement, $L I=$ low involvement, Trans = transformational, Info = informational, $S B I=$ Self-brand integration, $P D U=$ Passionate desire to use, $P E C=$ Positive emotional connection, $A S D=$ Anxiety separation distress, LTR = Long-term relationship, $A V=$ Positive attitude valence, $A S=$ Attitude strength. ${ }^{*} p$ $<0.05,{ }^{* *} p<0.01,{ }^{* * *} p<0.001$.

Taking a closer look at the interactions, the results per interaction are presented and discussed (see also Figures 4.3, 4.4, and 4.5). Three interaction effects of involvement and the personality traits extraversion and conscientiousness were established. The first interaction between involvement and extraversion was found with respect to the brand love element of passionate desire to use. For extroverted individuals, the PDU is greater for high-involvement than for low-involvement products. A greater passionate desire to use a brand belonging to the low-involvement product category occurs for introverted individuals. 
Ronald Voorn, Sabrina Hegner, and Ad Pruyn

Table 4.3 Summary of interactions effects

\begin{tabular}{llrrrrr}
\hline Interaction & $\begin{array}{l}\text { Dependent } \\
\text { Variable }\end{array}$ & $\begin{array}{c}\text { Sum of } \\
\text { Squares }\end{array}$ & df & $\begin{array}{c}\text { Mean } \\
\text { Square }\end{array}$ & F & Sig. \\
\hline Involvement * E & PDU & 3.641 & 1 & 3.641 & 3.709 & $.055^{*}$ \\
Involvement * C & PEC & 2.869 & 1 & 2.869 & 3,021 & $.083^{*}$ \\
Involvement * C & LTR & 7.928 & 1 & 7.928 & 3,009 & $.084^{*}$ \\
Motivation * E & LTR & 12.522 & 1 & 12.522 & 4.752 & $.030^{* *}$ \\
Motivation * O & LTR & 12.380 & 1 & 12.380 & 4.699 & $.031^{* *}$ \\
Motivation * O & SBI & 2.983 & 1 & 2.983 & 3.640 & $.057^{*}$ \\
Motivation * O & ASD & 2.641 & 1 & 2.641 & 3.086 & $.080^{*}$ \\
Motivation * C & AV & 9.061 & 1 & 9.061 & 3.461 & $.064^{*}$ \\
Motivation * N & AV & 8.526 & 1 & 8.526 & 3.257 & $.072^{*}$ \\
Motivation * A & AS & 11.522 & 1 & 11.522 & 2.929 & $.088^{*}$ \\
\hline
\end{tabular}

Note: $E$ = extroversion, $C=$ conscientiousness, $O=$ openness, $N=$ neuroticism, $A=$ agreeableness. Abbreviations used for dependent variables: $P D U=$ passionate desire to use, $P E C=$ positive emotional connection, $L T R=$ long-term relationship, $S B I=$ self-brand integration, $A S D=$ anxiety separation distress, $A V=$ attitude valence, and $A S=$ attitude strength. ${ }^{*} p<0.1,{ }^{* *} p<0.05$, ${ }^{* * *} p<0.01$.

The second and third interaction effect results from conscientiousness and involvement. If conscientiousness is low, the PEC as well as the LTR with a brand is greater for high-involvement than for low-involvement products. Only minor differences are detected though between lowand high-involvement products on both the PEC and LTR with a brand for high-conscientious individuals. So it seems the involvement with a product category is irrelevant to the development of brand love in the case of a highly conscientious consumer personality.

Looking at the motivational product type, two interactions with personality traits were found on the brand love dimension LTR (see Figure 4.4). More open consumers score higher on LTR when transformational products are involved, whereas this is the opposite for less open consumers who score higher on LTR in the case of informational products. Furthermore, a significant interaction between extraversion and the motivational type on LTR was found. For extroverted consumers, the difference between informational and transformational products is less relevant than for introverted consumers. Introverted consumers generate a greater score on long-term relationship in the case of transformational products.

Additionally, further interaction effects of the motivational product type and personality traits were found (see Figure 4.5). Openness and motivation resulted in two interactions on the brand love dimensions SBI and ASD. More open individuals experience greater SBI when 

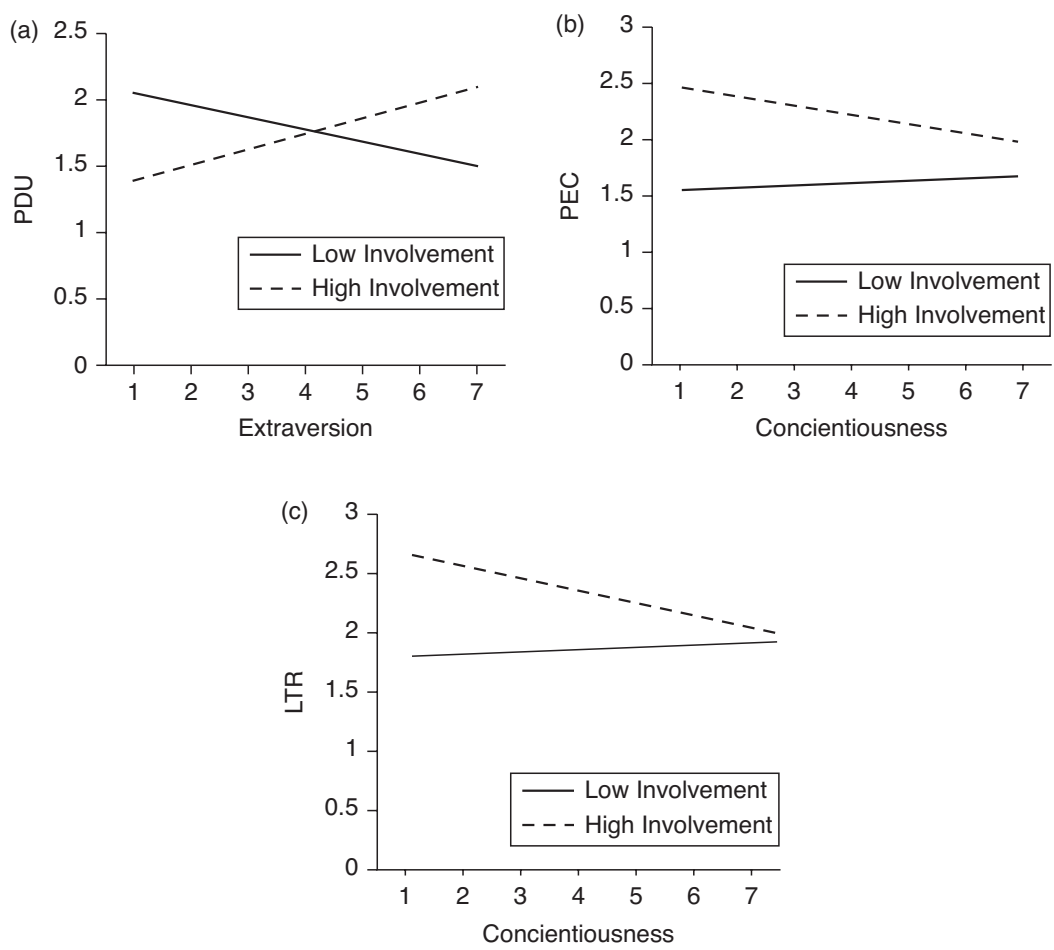

Figure 4.3 Interactions of extraversion and the involvement with the product category on brand love elements

transformational products are involved, whereas less open individuals experience greater SBI when informational products are involved. ASD on the other hand is high for open individuals no matter which motivation type is involved, whereas for less open individuals ASD is greater for informational products.

Furthermore, the results show interaction effects between conscientiousness as well as neuroticism and the motivational product type on $\mathrm{AV}$. If conscientiousness is low, $\mathrm{AV}$ is greater in the case of transformational product type, whereas if conscientiousness is high, transformational products generate only marginal higher effects on AV. If neuroticism is high, the score on $\mathrm{AV}$ is greater for informational products than for transformational products. The opposite is true if an individual is more neurotic. In this case transformational products score higher on AV. 


\section{PROOF}
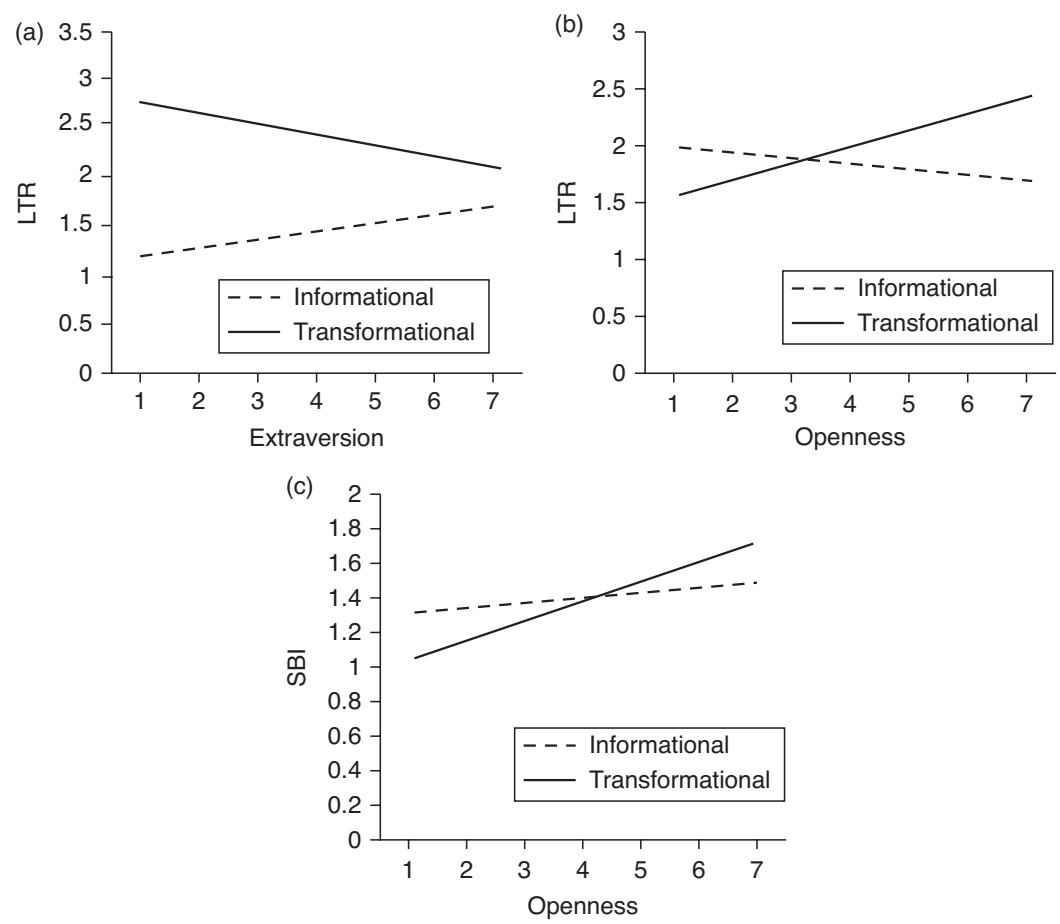

Figure 4.4 Significant, partial interactions between openness and extraversion, the motivational product type, and the long-term relationship

Additionally, we found an interaction effect between agreeableness and the motivational product type on AS. If respondents score high on agreeableness, their AS is higher when transformational products are involved. When the individual scores lower on agreeableness, a higher attitude strength is measured for informational products.

\section{Discussion}

In this final part of the chapter the following subjects will be addressed. First, the outcomes of this study will be summarized and discussed. Then theoretical implications will be presented, followed by limitations in combination with recommendations for further research. Finally, the recommendations for managers will be presented. 
(a)

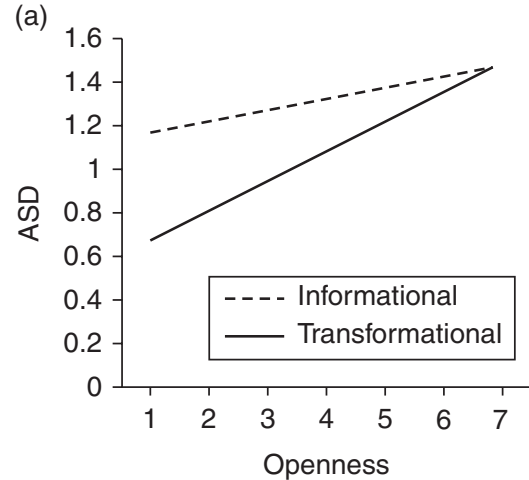

(c)

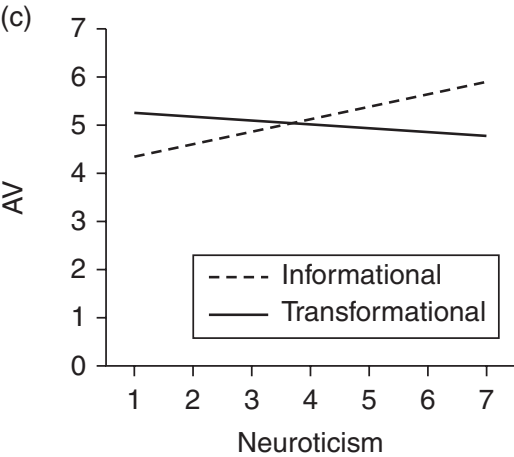

(b)

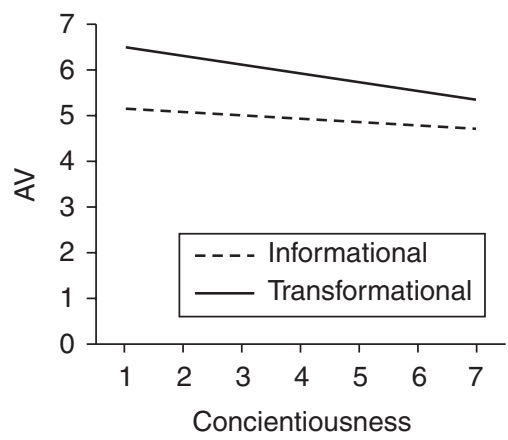

(d) 7

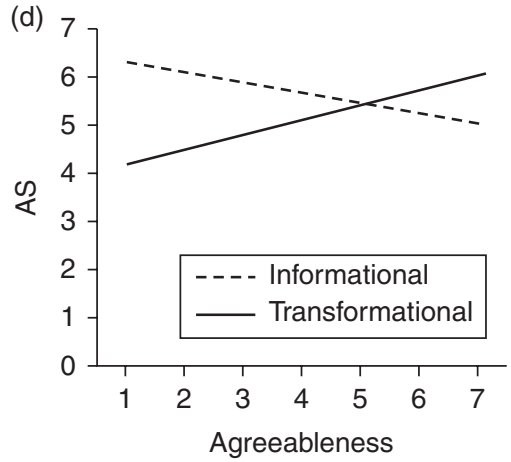

Figure 4.5 Other interactions between personality the motivational product type and brand love elements

\subsection{Summary and discussion of findings}

Understanding how to influence what drives consumers to form relationships with brands is of great importance to companies. The present study contributes to this by examining the influence of personality and product type on brand love, as well as the moderating influence of product type on the relationship between personality traits and brand love. For brand love, the model by Batra et al. (2012) was selected as it represents the most comprehensive understanding of the brand love concept to date. An online survey of 410 Dutch students demonstrated the existence of brand love and enabled the discovery of influential factors for building brand relationships.

The first objective of this research was to examine the influence of the big five personality traits (Costa and McCrae, 1992) on brand 


\section{PROOF}

love. This study found that a higher score on openness significantly predicts higher brand love. In other words, if individuals are more open to new experiences, they are able to generate more brand love.

The fact that this study found openness to significantly predict higher scores on brand love was new in comparison with the main findings of Rauschnabel et al. (2013). Openness entails the propensity to actively use one's imagination, be more sensitive to the aesthetics of objects, and demonstrate intellectual curiosity and adventurousness, as well as an inclination to prefer variety (McCrae and John, 1992). The four RP grid dimensions in combination span different psychological (high/low involvement, transformative, hedonistic, self-enhancement) and functional consequences (informational, problem solving). These all link to different big five facets. So openness seems to be the only common and logical distinguishing facet to significantly predict higher scores on brand love across the whole RP grid.

In the current study, the questions are answered on eight different brands belonging to four different RP grid categories (Rossiter et al., 1991). This might offer further explanation as to why the influence of the other personality traits on brand love are not confirmed. In contrast to fashion brands (as used in the study of Rauschnabel et al., 2013), which belong to the high-involvement and high-transformation RP category, the other RP categories offer less possibility for external selfexpression and are thus potentially of lower self-affirming value. Hence this might lead to other outcomes in relation to the influence of extraversion and neuroticism on brand love scores.

A further potential explanation for the differences on the personality scores between Rauschnabel et al. (2013) and this study might be a difference in the length of the big five questionnaire used. For this study, the ten-item personality inventory (TIPI) (Gosling et al., 2003) was applied as translated into Dutch by Hofmans et al., (2008). Although the TIPI is evaluated quite positively for its psychometric qualities (Gosling et al., 2003), it cannot be excluded that this might have created a difference in outcomes on the influence of extraversion and neuroticism on brand love.

The second objective of this study was to investigate the influence of the product category as measured by the RP grid on brand love. The results show that especially transformational products are able to generate a higher brand love score compared to informational products. Highinvolvement products did not result in higher overall brand love scores 
compared to low-involvement products. Therefore, hypothesis 5 was partly confirmed for overall brand love. Nevertheless, high-involvement products result in higher scores on the dimensions self-brand integration, positive emotional connection, and attitude strength compared to lowinvolvement products. So although it is easier for transformational than informational products to achieve brand love, the involvement with a product category is of less importance, and low-involvement brands can achieve the same scores on brand love as high-involvement brands.

Regarding the third objective of this study, the moderating influence of the product category on the relationship between personality and the brand love elements was examined. This study found significant interaction effects for all five personality traits on several brand love dimensions. The involvement with a product category interacts significantly with extraversion and conscientiousness, whereas the motivational type to which a product belongs shows strong interactions with openness in particular, but also extraversion, conscientiousness, neuroticism, and agreeableness.

This study found support for the view that a consumer's personality influences the level of brand love experienced. Openness significantly contributes to this. Additionally some effects were found for the moderating influence of the product category in the relationship between consumers and their love relationship with brands. Also the moderating effects of the specific grid quadrants were only noticeable for the motivational product type. The good news is that it is not a given that brand love is limited to certain product types. Very recent research by Huang and Mitchell (2014) also points this out and states furthermore that although great consumer brand relationships do require some imagination on the part of the consumer, it is quite feasible for marketers to evoke this no matter what product type is involved.

\subsection{Managerial implications}

Brand love can lead to considerable benefits for companies. In-depth knowledge of the personality of the target groups involved can aid marketers in designing effective brand support programs to generate brand love. Understanding which elements are important to generate brand love for the target group should be essential for every brand manager. In this study it was demonstrated that in the case of a brand love relationship openness positively predicts a higher level of love. Aiming to obtain more open consumers in their user portfolio is therefore a wise course of action for brand managers. 


\section{PROOF}

This study additionally demonstrates that the motivational category to which a brand belongs has a direct effect on the achieved brand love score. Brand managers with brands in the transformational product category therefore have a small advantage over other brand managers. The positive news for all other brand managers is that the game is completely open, however, since the moderation analyses show that different preferences for product types exist depending on the personality type.

Rossiter et al. (1991) explain that a product assigned to a certain category does not automatically mean that no brand love can be generated. Both this study and others (Huang and Mitchell, 2014) confirm this, too, which is very positive news, especially for lower-involvement and informational products. Great relations can be built with consumers as long as brands deliver on promise, evoke feelings and associations of a relationship, and use careful framing and branding. When marketers love their products and turn them into relevant brands for consumers, much is possible.

\subsection{Limitations and future research directions}

As is true for any study, the current study also has some limitations. Due to the selection of students, one should be careful not to generalize the results of this study for the whole population. For instance, students are known to score higher on the need for variety (van Trijp et al., 1996). This might potentially lead to lower brand relationship quality and therefore brand love scores. Nevertheless, the choice of students was to facilitate comparability with Batra et al. (2012) and Rauschnabel et al. (2013), who employed 49 percent students in their respondents set.

Also noteworthy is that respondents in this study were not orchestrated to only respond on the basis of a brand they loved. This is contrary to other brand love studies such as those of Batra et al. (2012) and Rauschnabel et al. (2013). In this study respondents were randomly assigned to a brand and product category. Thus it is likely that respondents were assigned to products they did not love. This was done to obtain as many real-life effects as possible. The brand love scores in this study would, however, have been higher if respondents had only scored on the brands they themselves already loved. This was not the right course of action, though, since we wanted to study the moderating effect of product category. Employing respondents according to the brands they love will not yield solid information on the moderating effects of product category as it will be of no influence. 
A further observation is that the number of females in this study is somewhat overrepresented compared to the Dutch statistics on students per gender (OCW, 2013), as in the comparable study on brand love by Rauschnabel et al. (2013). Theoretically this could have had an effect. Future research should investigate the relationship between gender and personality on brand love in greater detail.

Another point that needs to be raised is that in the setup of the current study, in which respondents were randomly assigned to products, the scores on brand love were rather low (as can be seen in Figures 4.3, 4.4, and 4.5). In future studies it might be interesting, therefore, to measure the incidence of the existence of brand love for products as such. How often it occurs is an interesting question in itself, both for academia as well as managers, because some, like Sharp (2010), for instance, argue that the existence of relationships and especially love between consumers and brands is highly questionable, "Love is a many-splendored thing, but not a big part of brand buying" (p. 110). It is, however, interesting to note that this current study demonstrated that even when respondents are randomly assigned to different products, brand love does appear to exist.

An additional interesting avenue for future research is related to cultural differences. A major difference between Germany and the Netherlands is on the dimension of masculinity or femininity (Hofstede and Hofstede, 2005; Hofstede and McCrae, 2004). Germany scores very high on masculinity (66), whereas the Netherlands scores very low (15) (Hofstede Center, n.d.). In countries that score high on masculinity (like Germany, where the Rauschnabel et al. (2013) study was performed), brands are often used as a sign of status confirmation. The opposite is the case in feminine cultures, such as in the Netherlands, where the current study was performed. In Dutch culture, one wants to fit in more than one wants to stand out (Hofstede and Hofstede, 2005). It seems therefore that Germans who score high on extraversion and neuroticism want to externally affirm their status with the brand of apparel they wear, as found by Rauschnabel et al. (2013). Further studies of the role of the big five and brand love in other cultures would augment the current knowledge on this subject.

\section{References}

Aaker, D. A. (1996) Building Strong Brands. New York: Free Press.

Aaker, J. (1997) "Dimensions of Brand Personality" Journal of Marketing Research, 34: 347-356. 


\section{PROOF}

Aaker, J. and Fournier, S. (1995) "A Brand as a Character, a Partner and a Person: Three Perspectives on the Question of Brand Personality" Advances in Consumer Research, 22: 391-395.

Albert, N., Merunka, D., and Valette-Florence, P. (2008) "When Consumers Love Their Brands: Exploring the Concept and its Dimensions" Journal of Business Research, 61(10): 1062-1075.

Aggarwal, P. (2004) "The Effects of Brand Relationship Norms on Consumer Attitudes and Behavior" Journal of Consumer Research, 31: 87-101.

Bagozzi, R., Yi, Y., and Phillips, L. (1991) "Assessing Construct Validity in Organizational Research" Administrative Science Quarterly, 36(3): 421-458.

Batra, R., Ahuvia, A., and Bagozzi, R. (2012) "Brand Love" Journal of Marketing, 76(2): 1-16.

Burns, A., Gillett, P., Rubinstein, M., and Gentry, J. (1990) “An Exploratory Study of Lottery Playing, Gambling Addiction and Links to Compulsive Consumption" Advances in Consumer Research, 17: 298-305.

Carroll, B. and Ahuvia, A. (2006) "Some Antecedents and Outcomes of Brand Love" Marketing Letters, 17(2): 79-89.

Christy, R., Oliver, G., and Penn, J. (1996) "Relationship Marketing in Consumer Markets" Journal of Marketing Management, 12(1-3): 175-187.

Claeys, C., Swinnen, A., and Vanden Abeele, P. (1995) "Consumers' Means-End Chains for 'Think' and 'Feel' Products" International Journal of Research in Marketing, 12(3): 193-208.

Costa, P. and McCrae, R. (1992) "Four Ways Five Factors are Basic" Personality and Individual Differences, 13(6): 653-665.

Eisinga, R., Grotenhuis, M., and Pelzer, B. (2012) "The Reliability of a Two-Item Scale: Pearson, Cronbach, or Spearman-Brown?" International Journal of Public Health, 58: 1-6.

Fayard, J., Roberts, B., Robins, R., and Watson, D. (2012) "Uncovering the Affective Core of Conscientiousness: The Role of Self-Conscious Emotions" Journal of Personality, 80(1): 1-32.

Fetscherin, M. and Conway Dato-on, M. (2012) "Brand Love: Investigating Two Alternative Love Relationships.” In: Fournier, S., Breazeale, M. and Fetscherin, M. (eds) Consumer-Brand Relationships: Theory and Practice. London: Routledge.

Fornell, C. and Larcker, D. F. (1981) "Structural Equation Models with Unobservable Variables and Measurement Error: Algebra and Statistics" Journal of Marketing Research, 18(3): 382-388.

Fournier, S. (1995) "Toward the Development of Relationship Theory at the Level of the Product and Brand" Advances in Consumer Research, 22: 661-662.

Fournier, S. (1998) "Consumers and Their Brands: Developing Relationship Theory in Consumer Research" Journal of Consumer Research, 24(4): 343-353.

Gosling, S., Rentfrow, P., and Swann, W. Jr. (2003) "A Very Brief Measure of the Big Five Personality Domains" Journal of Research in Personality, 37: 504-528.

Heller, D., Watson, D., and Ilies, R. (2004) "The Role of Person Versus Situation in Life Satisfaction: A Critical Examination" Psychological Bulletin, 130(4), 574-600. 
Hofmans, J., Kuppens, P., and Allik, J. (2008) "Is Short in Length Short in Content? An Examination of the Domain Representation of the Ten Item Personality Inventory Scales in Dutch language" Personality and Individual Differences, 45(8): 750-755.

Hofstede Center (n.d.) Country Scores. Available at: http://geerthofstede.com/ countries.html (Accessed on May 12 2013).

Hofstede, G. and Hofstede, G. (2005) Cultures and Organizations: Software of the Mind. Revised and expanded, 2nd ed. New York: McGraw-Hill.

Hofstede, G. and McCrae, R. (2004) "Personality and Culture Revisited: Linking Traits and Dimensions of Culture" Cross-Cultural Research, 38(1): $52-88$.

Huang, H. H., and Mitchell, V. W. (2014) "The Role of Imagination and Brand Personification in Brand Relationships" Psychology and Marketing, 31(1): $38-47$.

Izard, C. E. (1977) Human Emotions. New York: Plenum Press.

Izard, C. E., and Malatesta, C. Z. (1987) "Perspectives on Emotional Development. I: Differential Emotions Theory of Early Emotional Development." In: J. D. Osofsky (ed.): Handbook of Infant Development (2nd ed., pp. 494-554) New York: Wiley-Interscience.

Johnson, B. and Eagly, A. (1989) "Effects of Involvement on Persuasion: A MetaAnalysis" Psychological Bulletin, 106(2): 290-314.

Kubiak, T., Wiedig-Allison, M., Zgoriecki, S., and Weber, H. (2011) "Habitual Goals and Strategies in Anger Regulation" Journal of Individual Differences, 32(1): $1-13$.

Lin, L. (2010) "The Relationship of Consumer Personality Trait, Brand Personality and Brand Loyalty: an Empirical Study of Toys and Video Games Buyers" Journal of Product and Brand Management, 19(1): 4-17.

Matzler, K., Bidmon, S., and Grabner-Kräuter, S. (2006) "Individual Determinants of Brand Affect: the Role of the Personality Traits of Extraversion and Openness to Experience" Journal of Product and Brand Management, 5(7): 427-434.

McCrae, R. R. (2007) "Aesthetic Chills as a Universal Marker of Openness to Experience" Motivation and Emotion, 31, 5-11.

McCrae, R. and John, O. (1992) "An Introduction to the Five-Factor Model and Its Applications" Journal of Personality, 60: 175-215.

Mulyanegara, R., Tsarenko, Y., and Anderson, A. (2007) "The Big Five and Brand Personality: Investigating the Impact of Consumer Personality on Preferences towards Particular Brand Personality" Journal of Brand Management, 16(4): 234-247.

Nunnally, J. (1978) Psychometric Methods. New York: McGraw-Hill.

OCW (2013) Trends in Beeld 2012. Available at: www.trendsinbeeld. minocw.nl / grafieken/3_1_1_3.php (Accessed May 7 2013).

Ozer D. and Benet-Martınez, V. (2006) "Personality and the Prediction of Consequential Outcomes" Annual Review of Psychology, 57: 401-421.

Pang, J., Keh, H. T., and Peng, S. (2009) "Effects of Advertising Strategy on Consumer-Brand Relationships: A Brand Love Perspective" Frontiers of Business Research in China, 3(4): 599-620. 


\section{PROOF}

Petty, R., Cacioppo, J., and Schumann, D. (1983) “Central and Peripheral Routes to Advertising Effectiveness: The Moderating Role of Involvement" Journal of Consumer Research, 10(2): 135-146.

Petty, R. and Cacioppo, T. (1986) From Communication and Persuasion: Central and Peripheral Routes to Attitude Change. New York: Springer-Verlag.

Percy, L. and Rosenbaum-Elliott, R. (2012) Strategic Advertising Management. Oxford, UK: Oxford University Press.

Rammstedt, B. and John, O. (2007) "Measuring Personality in One Minute or less: A 10-item Short Version of the Big Five Inventory in English and German" Journal of Research in Personality, 41(1): 203-212.

Rauschnabel, P., Ahuvia, A., Ivens, B., and Leischnig, A. (2013) “Who Loves Brands? Exploring the Relationship between Personality, Interpersonal Love, and Brand Love" Proceedings from EMAC 2013. Istanbul, Turkey.

Roberts, Kevin (2004) Lovemarks: The Future Beyond Brands. Auckland, New Zealand: Reed Publishing (NZ) Ltd.

Roberts, B., Kuncel, N., Shiner, R., Caspi, A., and Goldberg, L. (2007) "The Power of Personality: The Comparative Validity of Personality Traits, Socioeconomic Status, and Cognitive Ability for Predicting Important Life Outcomes" Perspectives on Psychological Science, 2(4): 313-345.

Rossiter, J., Percy, L., and Donovan, R. (1991) "A Better Advertising Planning Grid" Journal of Advertising Research, 31: 11-20.

Rusting, C.L. and Larsen, R.J. (1997) "Extraversion, Neuroticism, and Susceptibility to Positive and Negative Affect" Personality and Individual Differences, 22(5): 607-612.

Sharp, B. 2010 How Brands Grow. Oxford, UK: Oxford University Press

Sheth, J. N. and Parvatiyar, A. (1995) "Relationship Marketing in Consumer Markets: Antecedents and Consequences" Journal of the Academy of Marketing Science, 23: 255-271.

Terracciano, A., McCrae, R. R., Hagemann, D., and Costa, P. T., Jr. (2003) "Individual Difference Variables, Affective Differentiation, and the Structures of Affect" Journal of Personality, 71: 669-703.

Thomson, M., MacInnis, D. J., and Whan Park, C. (2005) "The Ties That Bind: Measuring the Strength of Consumers: Emotional Attachments to Brands" Journal of Consumer Psychology, 15(1): 77-91.

Tobin, R. M., Graziano, W. G., Vanman, E. J., and Tassinary, L. G. (2000) "Personality, Emotional Experience, and Efforts to Control Emotions" Journal of Personality and Social Psychology, 79: 656-669.

Valta, K. S. (2013) “Do Relational Norms Matter in Consumer-Brand Relationships?” Journal of Business Research, 66(1): 98-104.

Van Trijp, H. C., Hoyer, W. D., and Inman, J. J. (1996) "Why Switch? Product Category: Level Explanations for True Variety-Seeking Behavior" Journal of Marketing Research, 33(3): 281-292.

Vaughn, R. (1980) "How Advertising Works: A Planning Model" Journal of Advertising Research, 20(5): 27-33.

Veloutsou, C. (2007) "Identifying the Dimensions of the Product-Brand and Consumer Relationship" Journal of Marketing Management, 23(1-2): 7-26. 
Watson, D., Clark, L. A., and Tellegen, A. (1988) "Development and Validation of Brief Measures of Positive and Negative Affect" Personality and Social Psychology, 54: 1063-1070.

Wilson, B. J. (2011) "An Investigation Into Three Consumer Constructs: Explaining The Nature of Relations Influencing Brand Relationship Quality" (Doctoral dissertation, RMIT University). 